\title{
Gender Transgression as Heresy: The Trial of Joan of Arc
}

Daniel Grigat and Gregory Carrier, University of Alberta

Joan of Arc has exercised a hold on the imagination, both medieval and modern, far exceeding her limited military achievements. It is perhaps for this reason that the trial of Joan on charges of heresy, culminating in her conviction and execution, is typically interpreted

188 in a cynical light. The primary theme of the literature is that the she was brought to trial and convicted for challenging the institutionalized power of state and church. The issue of gender transgression, which is repeated throughout the transcripts of Joan's trial, is either ignored or dismissed as irrelevant. It is typical of the medieval narrative that belief systems no longer accepted today are not taken seriously, and this is done through reducing them to familiar categories.

This paper aims to take the trial of Joan of Arc seriously by arguing that Joan really was a heretic because she was different from orthodox Christians in that she transgressed traditional gender roles. This issue played a major role in Joan's trial and one can scarcely read two paragraphs of the record without issues of gender transgression being raised and denounced. Furthermore, gender transgression was explicitly identified as amounting to heresy, and theological arguments were given by learned experts to justify this connection. This is not to deny that Joan was a heretic on other grounds; her obstinate refusal to submit herself to the Church militant and insistence on her ability to interpret her own revelations are crucial issues. Likewise, we do not intend to deny the political aspect of her trial, but rather to argue that the defense and reinforcement of traditional authority structures cannot be demarcated from the issue of heresy and gender transgression.

Past Imperfect

13 (2007) | (C) | ISSN 1192-1315 
In the context of the Hundred Years War, the military career of Joan of Arc was remarkably brief. Less than four hundred days passed between the dramatic leadership she displayed in lifting the siege of Orléans in May 1429 and her capture at Compiègne in May 1430. In spite of this, Joan of Arc has exercised a hold on the imagination, both medieval and modern, far exceeding her limited military achievements. Coley Taylor contends that Joan's trial "has become second in importance only to the Trial of Christ". ${ }^{1}$ Joan represents the ultimate underdog: an illiterate peasant woman who shook the foundations of English power in France at a time when power revolved around noble birth, extensive theological training, and, of course, the male gender. It is perhaps for this reason that the trial of Joan on charges of heresy, culminating in her conviction and execution, is typically interpreted in a cynical light. The trial, according to common wisdom, was little more than a political move by the English and their Church lackeys to discredit Joan's mission and bring it to an end.

Stuart Clark revolutionized the study of medieval knowledge systems by arguing that "a body of ideas that survived for nearly 300 years must have made some kind of sense and that this probably lay in its coherence with other things", 2 and by pointing out that there has been a poverty of research that treats these ideas as intrinsically meaningful and capable of inspiring actions. ${ }^{3}$ It is the intention of this paper to take the trial of Joan of Arc on charges of heresy seriously by arguing that Joan really was a heretic by virtue of the fact that she was different: she diverged physically from the accepted

\footnotetext{
${ }^{1}$ W. P. Barrett, The Trial of Jeanne d'Arc, introd. Coley Taylor (New York: Gotham House, 1932), vii.

${ }^{2}$ Stuart Clark, Thinking with Demons: The Idea of Witchcraft in Early Modern Europe (Oxford: Clarendon Press, 1997), viii.

${ }^{3}$ Clark, 5.
} 
norms of society and theologically from the teachings of the Church. Joan of Arc's difference was that she transgressed gender boundaries, and these transgressions were heresy. This issue played a major role in Joan's trial; one can scarcely read two paragraphs of the trial record without issues of gender transgression being raised. Further, gender transgression was explicitly identified as amounting to heresy, and theological arguments were given by learned experts to justify this connection. It is clear, then, that gender transgression was intrinsically meaningful and capable of inspiring action. This is not to deny that Joan was a heretic on other grounds; her obstinate refusal to submit herself to the Church militant in matters of the faith and insistence on her ability to interpret her own revelations is a prominent feature of her trial. Likewise, we do not intend to deny the political aspect of her trial, but rather to argue that the defense and reinforcement of traditional authority structures cannot be demarcated from the issue of heresy and difference vis-à-vis gender transgression.

In order to investigate gender transgression as heresy in Joan's trial, it is necessary to closely examine the trial record. However, the question arises as to whether the record can be taken as an accurate transcription of the trial. V. Sackville-West argues that objections to the trial raised by some of her judges, and clever answers given by Joan, have been omitted. Judge Frère Isambard recorded Joan as complaining, "Oh, you write the things which are against me, but not the things which are in my favor". Francoise Meltzer takes her analysis of the problem much farther in arguing that the trial is made inaccessible by the five centuries of conceptual distance separating us from an event in which all of the actors have

\footnotetext{
${ }^{4}$ V. Sackville-West, Saint Joan of Arc (London and Southampton: CobdenSanderson, 1936), 316-317.

Past Imperfect

13 (2007) | (c) | ISSN 1192-1315
} 
long since perished. ${ }^{5}$ It bears pointing out that five centuries of conceptual distance did not dissuade Meltzer from drawing her own conclusions regarding the trial.

Daniel Hobbins, whose translation of the trial is used as the basis for this paper, argues that the transcript is reliable. He notes that those judges who reported being coerced by Bishop Cauchon to falsify the record also reported resisting this pressure and recording the trial faithfully. Hobbins does admit that the transcript is not a transparent account of the trial insofar as the notaries abridged and summarized Joan's answers for her, and that Joan was not speaking on topics of her own choosing. ${ }^{6}$ A.E. Jones, in his defense of the trial proceedings, makes the point that Joan's heresy conviction was based upon Joan's own testimony and that the heresy charges contained no "statements of fact" with which Joan disagreed. ${ }^{7}$ Jones' assessment is mostly correct; Joan and her judges agreed that she heard voices and saw apparitions, that these apparitions commanded her to take up arms against the English in men's clothing and to reject the authority of the Church militant. The point of contention between Joan and her judges was whether the apparitions were angels or demons, and thus whether the actions and beliefs that followed from them represented the divine commandments of God or diabolically inspired heresy.

Whatever omissions or falsifications that the trial transcript may contain, this ultimately represents a problem for recovering Joan's voice from the trial. Insofar as this paper is concerned not

\footnotetext{
${ }^{5}$ Francoise Meltzer, "Between Mysticisms: The Trial of Joan of Arc," in Mystics: Presence and Aporia, eds. Michael Kessler and Christian Sheppard (Chicago: University of Chicago Press, 2003), 78.

${ }^{6}$ Daniel Hobbins, The Trial of Joan of Arc, trans. Daniel Hobbins (Cambridge: Harvard University Press, 2005), 13.

${ }^{7}$ A. E. Jones, The Trial of Joan of Arc (London: Barry Rose Ltd., 1980), 212.

Past Imperfect

13 (2007) | (c) | ISSN 1192-1315
} 
with Joan's voice, but rather with her judges' assessment of the relationship between gender transgression and heresy, falsification has little relevance. The transcript was written by Joan's judges and represents the voice that they wanted recorded for posterity. Meltzer's critique that five centuries separate us conceptually from the trial is a far more serious problem, but it is exactly this distance that this paper aims to narrow by uncovering gender transgression as heresy. The methodology employed is not one of pigeonholing the knowledge systems of the past into those of the present, but rather of "Going Medieval", described by John Kitchen as pinpointing the meaning of medieval religious activity within its own historical setting. ${ }^{8}$

In the secondary literature on Joan's trial, the primary theme is that she was brought to trial and convicted for challenging institutionalized power. R.M. Evans argues that "[t]he English all along insisted that her success... was not the consequence of a miracle worked by God, but that she was a witch who derived all her power from the Devil, and consequently was a heretic - that is, one who denied the sacred authority of the Church". ${ }^{9}$ However, despite Evan's tendency to take witchcraft and heresy beliefs seriously, he concludes that Joan was brought to trial for the suffering that she had caused the English and as such, the outcome of the trial was politically predetermined. ${ }^{10}$ Harold Brown likewise argues that Joan's fate "was entirely political". While she was condemned as a heretic "for hearing voices" and her "relapse" was facilitated by her

\footnotetext{
${ }^{8}$ John Kitchen, "Going Medieval: Paradigm Shifts and the Phenomenological Tendency in the Contemporary Encounter with Medieval Religion," in Method and Theory in the Study of Religion (vol. 14) (Toronto: Centre for Religious Studies, 2002), 404, 407.

${ }^{9}$ R. M. Evans, The Story of Joan of Arc (London: W. Smith, 1847), 152.

${ }^{10}$ Evans, 151-155. 
wearing of men's clothing, Brown argues that Joan's heresy was "essentially that of mounting effective political opposition to those with political power". ${ }^{11}$ W.S. Scott adds, "That Jeanne should be brought to trial was a political necessity to her enemies; not only must it be shown that the Dauphin's coronation was invalid, but for the morale of the English army it was essential to prove that the Armagnac success had a diabolical source". ${ }^{12}$

Other authors have emphasized the power of the Church, and the focus in Joan's trial of submitting her to the authority of the Church militant. Meltzer cites the 1415 Council of Constance as declaring that the Church, in deriving its power from Christ, is universal and infallible, and thus the only body with the competence and authority to interpret mystical experiences. ${ }^{13}$ Joan however made it abundantly clear that she placed the authority of her own revelations, which she identified with the Church triumphant, over that of the Church militant. ${ }^{14}$ Meltzer concludes that Joan's rejection of Church authority became the obsession of the trial, rather than any political danger she posed. ${ }^{15}$ A.E. Jones notes that Joan was held prisoner for six months before she was turned over to the ecclesiastical authorities for trial, and during this time numerous letters were written by the University of Paris and the office of the Inquisitor of France insisting that Joan be tried for "errors against the faith" ${ }^{16}$ Jones concludes that it is hard to imagine that Joan was put

\footnotetext{
${ }^{11}$ Harold O. J. Brown, Heresies: Heresies and Orthodoxy in The History Of The Church (Peabody: Hendrickson Publishers, 2000), 302.

${ }^{12}$ W. S. Scott, trans., The Trial of Joan of Arc, (London: The Folio Society, 1956), 9.

${ }_{13}^{13}$ Metzler, 89

${ }^{14}$ Barrett, 241.

${ }^{15}$ Metzler, 85.

${ }^{16}$ Jones, 15-16.
} 
on trial for political reasons; it was her rejection of the Church's authority to interpret her revelations that made her guilty of heresy. ${ }^{17}$

Coley Taylor stresses the difficulty of the position in which Joan's judges were placed: many of them had been on the English payroll and were "avowedly her enemies", ${ }^{18}$ but they must have "gone in fear and trembling to the opening of the trial...for all their 194 | knowledge of their authority and power". ${ }^{19}$ The implication is clear: Joan was not the only one who was placed in a difficult position visà-vis this trial: her judges were as well, and it is precisely this difficulty that has not always been considered, namely that Joan's judges had to consider factors that were not political, particularly theology and gender. However, most authors who choose to acknowledge the issue of gender transgression dismiss it as irrelevant or inexplicable. George Anastaplo accepts the power motives of both state and Church in Joan's trial. He states that Joan was tried by the English and convicted of heresy for rejecting the authority of the Church militant. Anastaplo argues that we must separate the critical issue of submission to the Church from secondary issues such as the wearing of male clothing. ${ }^{20}$ Hobbins argues that the trial is inescapably political as Joan's claims threatened to undermine the legitimacy of English rule in France. However, the theological task of establishing Joan as a heretic opened the door to issues such as adopting men's clothing and refusing to submit to the Church: "Joan of Arc was tried as a heretic not because she was a woman, although that factor played an important part, nor because she heard voices,

\footnotetext{
17 Jones, 13.

${ }^{18}$ Barrett, xi.

${ }^{19}$ Barrett, xiii.

${ }^{20}$ George Anastaplo, On Trial: From Adam and Eve to O.J. Simpson (Lanham, Maryland, Lexington Books, 2004), 214-215.
}

Past Imperfect

13 (2007) | (c) | ISSN 1192-1315 
but because she heard voices telling her to attack the English". ${ }^{21}$ Just what "important part" gender played is never examined by Hobbins. Sackville-West argues that the trial was politically motivated and predetermined, but she notes with confusion that gender questions permeated the trial and Joan's clothing was "persecuted all out of proportion". She states that "It is difficult to understand exactly why the doctors and jurists laid such stress upon her choice of clothes...it seems as if neither heresy or sorcery could enter into it". 22

Only Nancy Bradley Warren takes the issue of gender seriously by equating Joan's gender transgressions with a threat to English authority. Warren argues that Joan challenged the English at the fault line between gender and politics: she challenged English manhood by taking up arms and defeating their armies, she threatened the English state by challenging their French possessions, and she threatened the English monarchy (if only symbolically) by interfering in the issue or royal succession through women - a key issue in the struggle between the royal houses of Lancaster and York for the throne of England. ${ }^{23}$

In order to understand the importance that gender transgression played in Joan's trial it is necessary to get a feel for the frequency with which gender issues were raised in the trial, and the prominence that was given to them. Contrary to the opinions of some authors, it is hard to see how gender could be understood as merely a secondary, or technical, issue. In fact, many technical issues of heresy were raised, such as Joan's denial of the doctrine of free will when she reported being "tempted" to jump from the tower of her

${ }^{21}$ Hobbins, 20-21.

${ }^{22}$ Sackville-West, 325-326.

${ }^{23}$ Nancy Bradley Warren, Women of God and Arms: Female Spirituality and Political Conflict, 1380-1600 (Philadelphia, University of Pennsylvania Press, 2005), 58, 60 . 
imprisonment, ${ }^{24}$ however these issues were never given a modicum of the attention that gender issues were.

Ecclesiastical procedure called for a preparatory trial to take place before a formal trial to establish if the accused was reasonably suspected of heresy. The opening statement of Joan's preparatory trial begins with a list of those in attendance and quickly moves on to 196 the issue of why the trial has been called to order. "The report has now reached many places that this woman, utterly disregarding the honor due the female sex, throwing off the bridle of modesty, and forgetful of all feminine decency, wore the disgraceful clothing of men, a shocking and vile monstrosity. Her presumption reportedly grew until she dared to perform, to speak, and to publicize many things contrary to the Catholic faith and injurious to its articles". ${ }^{25}$ It is notable that the opening statement included no mention of sorcery, or of rejecting political authority. The central function of a preparatory trial for heresy is to establish notoriety, and this was established through the demonstration that Joan was well known to have transgressed gender boundaries.

Following the introductory statements, the preparatory trial to establish if she should be formally tried for heresy consisted of six formal and five informal sessions. Of the six formal sessions, held between February 21st and March 3rd 1431, in all but one Joan was questioned on why she insisted on wearing shameful clothing, on whose advice she had dressed as such, whether she thought that wearing men's clothing was sinful and against the commandments of God, whether she had accepted the sacraments in such clothing, and finally if she would agree to wear women's clothing. Only in the fifth formal session, focusing on sorcery and divination, did Joan's

\footnotetext{
${ }^{24}$ Hobbins, 140.

${ }^{25}$ Hobbins, 33.
} 
gender transgression escape scrutiny. ${ }^{26}$ During each of the five informal sessions (held in Joan's cell between March 12th-March 25th), the questions regarding Joan's choice of clothing were reiterated and she was repeatedly asked to abandon men's clothing in order to hear mass and receive the Eucharist, which Joan obstinately refused. ${ }^{27}$

The ordinary trial, which followed the preparatory trial, sought to establish the grounds on which Joan was guilty of heresy and consisted of two main parts. In the first part, seventy "articles" were read to Joan, each one of which was suspected of consisting of heresy; Joan was given a chance to refute the claims. If Joan failed or refused to refute the articles they were to be taken as confessed. The articles, read to Joan on March 27th, began with an opening statement that, in addition to accusing Joan as a sorceress and schismatic, stated that Joan, "[having] wholly forsaken the decency and reserve of her sex, utterly without modesty and shamelessly having taken the disgraceful clothing and state of armed men... for these and other reasons [she is] an abomination to God and man, a transgressor of divine and natural laws and ecclesiastical discipline... a heretic, or at least greatly suspected of heresy". ${ }^{28}$

Of the seventy articles brought against Joan, fourteen clearly accused her of gender transgressions. Joan was accused of consorting with men and gaining knowledge of horsemanship and arms (article 8); disrespecting the commands of her father (article 10); of wearing men's clothing, cutting her hair like a man's, and taking up arms (article 12); wearing men's clothing and attributing this to the command of God and His saints (articles13 and 14); forgoing the

\footnotetext{
${ }^{26}$ Hobbins, 48-82.

${ }^{27}$ Hobbins, 93-117.

${ }^{28}$ Hobbins, 124.
} 
sacraments rather than men's clothing (article 15); refusing sound advice to abandon men's clothing and take up tasks "proper to her sex" (article 16); practicing divination while wearing men's clothing (article 17); encouraging violence (article 18); countless [and unnamed] evils "inappropriate to her sex" (article 38); wearing men's clothing at the instigation of the devil (article 40); taking command over men (article 53); refusing the company of women in favor of men (article 54); making ridiculous statements unbefitting a woman (article 63). ${ }^{29}$

After deliberating on the seventy articles that Joan was understood to have confessed to through her lack of an adequate defense, they were reduced to twelve articles of heresy that were submitted to many learned masters for their theological opinion. These were the twelve articles upon which Joan was convicted; they were read to her on April 5th. Article one stated that Joan had taken on the clothing of men, had chosen to forgo Mass and the Eucharist rather than abandon her clothing, and had attributed her behavior to the commandment of God delivered through Saint Catherine and Saint Margaret. The article further charges that Joan left home against the will of her father to join the company of men and to rarely, if ever, share the company of women. ${ }^{30}$ Article five restates these charges with an elaborate description of the clothing and haircut that Joan had adopted, and the observation that Joan's attire left "nothing about her to indicate the female sex except what nature gave her to distinguish her sex". ${ }^{31}$ Article seven charged that Joan had received men's clothing and arms, and had taken knights,

\footnotetext{
${ }^{29}$ Hobbins, 127-160.

${ }^{30}$ Hobbins, 158.

${ }^{31}$ Hobbins, 159-160.
} 
squires, servants and soldiers under her command in order to wage war. $^{32}$

The emphasis upon gender transgression did not end with the completion of her formal trial. Tied to the stake on May 24th, Joan was compelled to sign a confession repenting for her sin of wearing men's clothing against all natural decency and the virtue of the female sex. ${ }^{33}$ The Church commuted her sentence to life imprisonment on the condition that she abandon her errors of the faith, specifically, that she adopt women's clothing and have her shameful male haircut shaved off. ${ }^{34}$ When the judges came to her cell four days later and found Joan once again dressed as a man, the documents record six paragraphs of questioning on why Joan had resumed her gender bending before the issue of her apparitions was raised. The twenty-seven masters who were present signed a document convicting Joan of relapsed heresy for being led by the devil into taking on men's clothing against the command of the Church and for telling witnesses that her voices had returned to her. ${ }^{35}$

It should now be well-established that gender transgression played a prominent, rather than merely a secondary, role in Joan's trial. Hobbins' claim that politics provided the ultimate motivation for the trial, and that gender transgression was only utilized to establish heresy, is difficult to assess. It is unclear what evidence could ever be produced to refute Hobbins' claim, and as such it seems to be an "unfalsifiable" hypothesis. However, for our purposes it is enough to investigate how gender transgression was used to establish heresy in Joan's trial, whatever is made of hidden motivations. In the process it will be possible to address Sackville-

\footnotetext{
${ }^{32}$ Hobbins, 160.

${ }^{33}$ Hobbins, 192.

${ }^{34}$ Hobbins, 195

${ }^{35}$ Hobbins, 199.
}

Past Imperfect

13 (2007) | (c) | ISSN 1192-1315 
West's sense that the gender component of the trial is inexplicable. The overwhelming emphasis in Joan's trial placed upon behaviors that transgressed accepted gender boundaries makes sense once we recognize that transgressing gender boundaries was heresy.

As previously mentioned, the twelve articles used to convict Joan were submitted to various theological experts for their opinion as to whether they amounted to heresy; the responses were recorded in the trial transcript. The Church relied upon its extensive theological arsenal to develop the notion of difference - that is, Joan as a physical and theological deviant - which would serve as the framework in which to situate and develop the issue of Joan's gender transgressions. The first response to be returned was recorded on April 12th: it was a notarized statement of sixteen theologians' opinions on the twelve articles. They concluded that "to say that she has done well all that is contained in the fifth article [adopting the clothing and haircut of a man], besides what is stated in the first article about not receiving the sacraments of Eucharist [because she would not abandon men's clothing]... and to say that she has done all these things by God's command - these are blasphemies against God and errors in the faith" (emphasis added). ${ }^{36}$

The charge that Joan would not receive the Eucharist was a significant one. Peter the Venerable had developed "a coherent system of thought" that stressed the importance of the Church and society in the twelfth century. ${ }^{37}$ The Church was important to Peter socially because of the social value of the Mass: Jews and Muslims were excluded (and demonized) because they did not believe in Christ's sacrifice and its communal repetition through the Mass, a

\footnotetext{
${ }^{36}$ Hobbins, 163.

${ }^{37}$ Dominique Iogna-Prat, Order and Exclusion: Cluny and Christendom Face Heresy, Judaism, and Islam (1000-1150), trans. Graham Robert Edwards (New York: Cornell University, 2002), 103.
}

Past Imperfect

13 (2007) | (c) | ISSN 1192-1315 
significant heresy in its own right. ${ }^{38}$ To cut oneself off from the wider group would be to label oneself as part of the "other", specifically the unchristian other. This notion could also be manipulated to provide a weapon in the Church's arsenal: one did not necessarily have to cut oneself from society at large. The Church could choose to identify and label people and sects and cut them off from both Church and society. As such, Joan clearly set herself apart from orthodox Christianity through her gender transgressions and the Church relied upon its theological authority to reinforce Joan's difference vis-à-vis her gender transgressions.

On May 2nd, Archdeacon Jean de Chatillion, a professor of theology, was brought to Joan's cell to explain to her the grounds upon which she was in error of divine canon. On the issue of wearing men's clothing, Chatillion concluded, "All these things are against the commandment of God in Deuteronomy 22: 'A woman shall not be clothed with man's apparel.' They are against the teaching of the apostle [Paul] when he says that a woman should cover her head. ${ }^{39}$ They are against the prohibitions of the Church declared in holy general councils. They are against the teaching of the saints and doctors, both in theology and in canon law". ${ }^{40}$ On Joan's claim that she wore men's clothing by God's command, the archdeacon concluded, "Now, to say that someone is doing right by contradicting the teachings of the saints and the commandments of God and the apostles by scorning the teaching of the Church out of a perverse desire to wear unseemly and disgraceful clothing is an error in the faith. And if someone were to defend this obstinately, she would lapse into heresy. Further, she even wanted to assign these sins to

${ }^{38}$ Iogna-Prat, 275-357, especially 316-319 and 355-357.

${ }^{39}$ The Holy Bible [Douay-Rheims version] (Fitzwilliam, New Hampshire: Loreto Publications, 2004), 1 Corinthians 11:3-16.

${ }^{40}$ Hobbins, 173. 
God and the saints, whom she therefore blasphemes by assigning to them what is improper" (emphasis added). ${ }^{41}$ Put baldly, the archdeacon stated that the Church recognized Joan's apparitions to be demons who had transformed themselves into the appearance of angels, an act permitted by God to punish the presumptuous. If Joan was permitted to claim that the diabolical suggestions of her

202 apparitions were divine commands, "the apostasy of the people could follow from this, the creation of new sects, and many other evils, to the ruin of the Church and the catholic people". ${ }^{42}$

The notion of sectarianism is central to the idea of heresy: by committing gender transgressions, Joan was showing herself to be different from orthodox Christians, which clearly meant that she was heretical. In his letter to the Galatians, Saint Paul exhorts them to stand by their Christian faith: if they do not, they will be guided by the inferior body, which is susceptible to "fornication, uncleanness, immodesty, luxury, idolatry, witchcrafts, enmities, contentions, emulations, wraths, quarrels, dissensions, sects... and the like." Read in the context of Joan, Paul's implication is clear: allowing the formation of a sect would only lead members of the sect to the vices that Paul listed; Joan had already transgressed in terms of gender which vice would be next? As such, Joan was doubly harmful, both to herself, and to the larger community because she was tempting others, particularly through her success at Orléans and facilitating the Dauphin's coronation. Joan, through her actions and subsequent fame, could potentially influence others who would emulate her actions and form a sect, eroding the authority of the one true Church, which was a very real and tangible concern.

\footnotetext{
${ }^{41}$ Hobbins, 173-174.

${ }^{42}$ Hobbins, 174.

${ }^{43}$ The Holy Bible, Galatians 5:19-20.

Past Imperfect

13 (2007) | (c) | ISSN 1192-1315
} 
On May 19th, the formal responses from the Faculties of Theology and Canon Law at the University of Paris arrived, although only a brief summary of their contents was recorded in the trial record. The letter from the Faculty of Theology was summarized as condemning all twelve articles as heresy. The letter from the Faculty of Canon Law was recorded as stating that Joan "is an apostate for cutting off her hair and rejecting women's dress [and] she errs in the faith for enduring anathema for a long time and preferring to forgo the body of Christ and confession rather than wear women's dress". ${ }^{4}$

The theological arguments put forth in Joan's trial make it clear that gender transgression violated both God's commands as stated in divine scripture and also the canon law of the Church. The refusal to hear Mass and to accept the Eucharist in genderappropriate clothing likewise constitutes the heresy of rejecting God's commands and His Church on earth. Finally, the attribution of gender transgressions to the command of God, His angels, and His saints, constitutes heresy. Gender transgressions constitute an example of heresy because, by contradicting the teachings of the Catholic Church, they threaten to undermine the universal Church through the creation of new - dangerous - religious sects.

Gender transgression is not an issue that excludes traditional power analysis. In fact, the issue of gender transgression as heresy cannot be demarcated from the defense and reinforcement of traditional power structures. Joan of Arc challenged political authority by attempting to overthrow the English-Burgundian alliance in favor of a united French kingdom under a single French ruler. In doing so, she attempted to establish herself as a political authority, a position that was supposed to be denied to her a priori on

\footnotetext{
${ }^{44}$ Hobbins, 182-183.

Past Imperfect

13 (2007) | (c) | ISSN 1192-1315
} 
the grounds of both class and gender. The fact that this peasant girl was taken seriously only increased the danger she posed to the "natural order of things". That Joan lifted the siege of Orléans and brought to an end a period of English military dominance in France was reason enough to want her dead - the fact that this reversal of the English fortunes in France was carried out by a member of the 204 | "weaker sex" threatened male domination of military affairs. It is hard to imagine how "taking command over men" could be considered heresy if attributed to a man.

Joan's challenge of the power of the Church has been much discussed. Church power rested upon the premise that the Church militant was infallible. Positions of leadership and authority within the Church rested upon extensive theological training - these positions were closed to illiterates and to women. Joan, an illiterate peasant girl, who claimed that her religious knowledge came directly from God and superseded the authority of the Church militant challenged both the Catholic Church's domination of religion and male domination of the Church. Stuart Clark tells us in his study of witchcraft that it hardly needs to be stated that this is one of the ideas "held by those who, in one way or another, were anxious to preserve orthodoxy, and who constructed the difference between the normal world and the world of witchcraft in such a way as to legitimate the institutions to which they belonged or otherwise supported" ${ }^{45}$

R.I. Moore contends that being a heretic, unlike being a leper or a Jew, derives its meaning from being labeled a heretic by an authority, and as such is inescapably political. ${ }^{46}$ Moore draws upon the deviance theory of Émile Durkheim to argue that labeling

\footnotetext{
${ }^{45}$ Clark, x.

${ }^{46}$ R. I. Moore, The Formation of a Persecuting Society: Power and Deviance in Western Europe, 950-1250 (Malden, MA: Blackwell Publishing, 2005), 68.

Past Imperfect

13 (2007) | (c) | ISSN 1192-1315
} 
individuals or groups as deviant functions to reinforce social norms, norms that are created by those in power. Persecution is a reaction to anxiety, anxiety that traditional power structures are being undermined. Moore concludes that "[a]nxieties of this kind are very commonly directed against women in societies which, in one way or another, give them both high value and low status". 47 Stuart Clark agrees that the gender connection can be found in societies that marginalize women, thus making them more susceptible to charges of social deviance when they became anomalous in relation to maledefined social norms. Further, that gender transgression constituted a crime against God and society stemmed from the tendency in the medieval mind to view the world as consisting of binary opposites: "There was something specifically and intrinsically demonic in vehicles for inversion like misrule, masking, and transvestitism", which switched the polarities of male and female. He continues this thought: "Who could be the author of this 'inversion, alteration, and disguise' but the devil?"48 To Joan's judges she really was a demonically inspired heretic, for she turned their world upside-down and challenged the legitimacy of institutionalized power.

The Aethiopians say that their Gods are snub-nosed and black-skinned, and the Thracians that theirs are blueeyed and red-haired. If only oxen and horses had hands... then horses would draw the figures of their Gods like horses, and oxen like oxen, and would make their bodies on the model of their own.

- Xenophon ${ }^{49}$

\footnotetext{
${ }^{47}$ Moore, 99-101.

${ }^{48}$ Clark, 21-22.

${ }^{49}$ Quoted in Arnold J. Toynbee, A Study of History, vol. 1 (London: Oxford University Press, 1934), 1.
}

Past Imperfect

13 (2007) | (c) | ISSN 1192-1315 
Apps and Gow conclude their study on male witches with a note on historical ethics: when historians address historical actors, they must "listen carefully to their self-understandings and selfdescribed motivations before we import our categories into the past to study them. ${ }^{, 50}$ In the first volume of A Study of History, Arnold Toynbee illustrated the relativity of historical thought by quoting the Greek philosopher Xenophon's argument that every culture creates their gods in their own image. Toynbee's point was that different cultures, like individuals, create and perceive reality in a selfreflexive way. Since the American and French revolutions entrenched the separation of church and state in the western world, the concept of "heresy" as a crime has largely evaporated. Furthermore, the concept of enforcing gender boundaries has grown increasingly distasteful to "modern" sensibilities. Our contemporary categories of meanings and ethics cannot be imported into the world of fifteenth-century Europe, where gender transgression was taken seriously. The overwhelming frequency with which it came up during the trial undermines any attempt to label it as merely a secondary, and therefore irrelevant, concern. Gender transgression was understood as heresy. Pains were taken to label Joan's actions and assertions which transgressed gender boundaries as a violation of the laws of God and the Church, and as a heresy that, if not stamped out, would lead to the flourishing of sects in opposition to the universal Church. Finally, gender transgression was a challenge to the established power structures. It challenged the military and political power of the English, the absolute religious authority of the Church, and the privileged place of men in a male-dominated society.

\footnotetext{
${ }^{50}$ Lara Apps and Andrew Gow, Male Witches in Early Modern Europe (Manchester: Manchester University Press, 2003), 152.

Past Imperfect 13 (2007) | (c) | ISSN 1192-1315
} 
Past Imperfect

13 (2007) | (c) | ISSN 1192-1315 